This item was submitted to Loughborough's Research Repository by the author.

Items in Figshare are protected by copyright, with all rights reserved, unless otherwise indicated.

\title{
Mobility and bioavailability of sediment phosphorus in urban stormwater ponds
}

PLEASE CITE THE PUBLISHED VERSION

https://doi.org/10.1029/2018WR023419

\section{PUBLISHER}

(c) American Geophysical Union. Published by Wiley

\section{VERSION}

VoR (Version of Record)

\section{PUBLISHER STATEMENT}

FROST, P.C. .... et al., 2019. Mobility and bioavailability of sediment phosphorus in urban stormwater ponds. Water Resources Research, 55(5), pp. 3680-3688. To view the published open abstract, go to https://doi.org/10.1029/2018WR023419

\section{LICENCE}

CC BY-NC-ND 4.0

\section{REPOSITORY RECORD}

Frost, Paul C., Clay Prater, Andrew B. Scott, Keunyea Song, and Marguerite A. Xenopoulos. 2019. "Mobility and Bioavailability of Sediment Phosphorus in Urban Stormwater Ponds". figshare.

https://hdl.handle.net/2134/37898. 


\section{Water Resources Research}

\author{
RESEARCH ARTICLE \\ 10.1029/2018WR023419 \\ Key Points: \\ - Phosphorus $(\mathrm{P})$ retention in \\ stormwater ponds may be \\ constrained by the generation of \\ nonbioavailable but highly mobile \\ dissolved organic $\mathrm{P}$ \\ - Dissolved organic phosphorus was \\ especially prevalent and mobile in \\ urban pond sediments and released \\ regardless of oxygen concentrations \\ - While high P demand was evident, \\ algal growth was limited in ponds \\ with especially low dissolved $\mathrm{N}: \mathrm{P}$ \\ ratios
}

Supporting Information:

- Supporting Information S1

Correspondence to:

P. C. Frost,

paulfrost@trentu.ca

Citation:

Frost, P. C., Prater, C., Scott, A. B., Song, K., \& Xenopoulos, M. A. (2019). Mobility and bioavailability of sediment phosphorus in urban stormwater ponds. Water Resources Research, 55. https://doi.org/10.1029/2018WR023419

Received 11 JUN 2018

Accepted 9 APR 2019

Accepted article online 18 APR 2019

(C)2019. American Geophysical Union. All Rights Reserved.

\section{Mobility and Bioavailability of Sediment Phosphorus in Urban Stormwater Ponds}

\author{
Paul C. Frost ${ }^{1}$ (D), Clay Prater ${ }^{2}$ (D), Andrew B. Scott ${ }^{1}$, Keunyea Song ${ }^{1}$, \\ and Marguerite A. Xenopoulos ${ }^{1}$ iD \\ ${ }^{1}$ Department of Biology, Trent University, Peterborough, Ontario, Canada, ${ }^{2}$ Environmental and Life Sciences Graduate \\ Program, Trent University, Peterborough, Ontario, Canada
}

\begin{abstract}
Stormwater ponds can serve as retention hotspots for phosphorus (P) moving out of the urban environment. This retention may be reduced by $\mathrm{P}$ speciation that reduces the bioavailability of $\mathrm{P}$ to primary producers and alters its mobility in sediments. Here we examined the mobility and fate of dissolved $\mathrm{P}$ in urban stormwater ponds with a set of complementary field measurements and short-term laboratory and field experiments. We measured the types and amount of $\mathrm{P}$ in water column and sediments of urban stormwater ponds. We further assessed the mobility of different $\mathrm{P}$ types in pond sediments in the field and rates of $\mathrm{P}$ release from sediment cores maintained under laboratory conditions. Finally, we assessed $\mathrm{P}$ uptake rates by pond algal communities using short-term bioassay experiments. We found that dissolved organic $\mathrm{P}$ was highly prevalent in urban pond water and sediments and that this type of $\mathrm{P}$ was mobile within sediments and could be released under high or low $\mathrm{O}_{2}$ conditions. We also found highly variable $\mathrm{P}$ demand by algae among stormwater ponds and that algal growth responses to $\mathrm{P}$ was correlated to water column N:P ratios. Altogether, our results indicate an important role for organic phosphorus cycling in urban stormwater ponds, which likely constrains the overall retention efficiency in these aquatic ecosystems.
\end{abstract}

\section{Introduction}

Excessive inputs of phosphorus (P) in to urban environments contribute to the degradation of water quality in downstream lakes and rivers (Carpenter et al., 1998; Kaye et al., 2006). While the specific sources of $P$ within urban landscapes can be difficult to identify (Easton et al., 2007), significant amounts of $P$ are added to stormwater by lawn waste, soil erosion, leaf detritus, fertilizers, and pet waste (Paul \& Meyer, 2001). This P is transported downstream by overirrigation, snow melt, or rain events, all of which create or strengthen hydrological links between the urban landscape and aquatic ecosystems (Walsh et al., 2005). The mitigation of urban P has largely focused on end of pipe management in many regions of North America (Walsh et al., 2005). One widely used approach has been to embed small ponds downstream of the developed environment but upstream of receiving waters (Tixier et al., 2011). These small ponds remove nutrients by way of particle sedimentation, physical absorption, and uptake by resident biota, all of which could improve water quality downstream (Comings et al., 2000). While promoted as a possible nutrient sink (Brunberg \& Boström, 1992; Maavara et al., 2015), stormwater ponds have been found to have highly variable (10-90\%) and generally quite low (average $~ 30-40 \%$ ) retention efficiencies of P (Gold et al., 2017a, 2017b; Sonderup et al., 2016).

Variable and generally low retention efficiency of $\mathrm{P}$ in urban stormwater ponds may be partly explained by internal pond $\mathrm{P}$ biogeochemistry. Low $\mathrm{P}$ retention efficiency could result if this nutrient has variable reactivity among multiple dissolved and particulate forms, which limits its incorporation into resident microbes and reduces retention through subsequent sedimentation (Sinke et al., 1990; Søndergaard et al., 1993). This explanation of low $\mathrm{P}$ efficiency is partly premised on a more complicated P biogeochemistry (e.g., different forms of $\mathrm{P}$ that undergo multiple types of transformations) in stormwater ponds beyond that of simple sedimentation of particulate $\mathrm{P}$ forms. For example, following the breakdown of organic matter in sediments, dissolved $\mathrm{P}$ could accumulate in interstitial water and move back into surface waters of stormwater ponds. In addition, this dissolved $\mathrm{P}$ may be in inorganic (i.e., soluble reactive P, SRP) or organic (dissolved organic P, DOP) forms. DOP in stormwater ponds has been previously classified into two categories, phosphodiester (DP) and phosphomonoester (MP), with a preponderance of DP in both the water column and sediments (Song et al., 2015, 2017). While DP is generally considered to be relatively less refractory than MP (Turner 
\& Newman, 2005), its mobility in pond sediments and availability to primary producers in stormwater ponds remains largely unknown.

A related explanation for low pond $\mathrm{P}$ retention is that $\mathrm{P}$ does not remain in sediments, which thus fail to act as a permanent sink (Søndergaard et al., 1993; Song et al., 2015; Song \& Burgin, 2017). Internal P loading from sediments in freshwater ecosystems is generally thought to be controlled by oxygen concentrations in overlying water (Søndergaard et al., 2003). Oxygenic conditions can strongly limit the release of inorganic $\mathrm{P}$ from sediments by affecting redox potentials especially if $\mathrm{P}$ is largely bound to Fe or $\mathrm{Al}$ minerals (Hupfer \& Lewandowski, 2008; Søndergaard et al., 2003). In stormwater ponds, hypoxia near the sediments can alter redox conditions and result in P release from sediments (Duan et al., 2016; Gold et al., 2017a, 2017b). The ubiquity of internal releases of inorganic P from shallow, well-mixed urban ponds is doubtful, however, as oxygen only controls $\mathrm{Fe}$ or Al-bonded $\mathrm{P}$, not other forms of $\mathrm{P}$ in sediments. It appears other forms of $\mathrm{P}$ (e.g., organic bound P) are highly prevalent in pond sediments (Song et al., 2017) and that these forms may be released regardless of oxygen concentrations in the water column.

The release of P, largely in DOP forms, from pond sediments could reduce longer-term (e.g., years) storage and retention of $\mathrm{P}$ in sediments and subsequently lead to greater $\mathrm{P}$ export downstream. If released $\mathrm{P}$ is bioavailable, it may be quickly removed from the water column by microbial communities and sink back into sediments. There should be no net effect of such "closed" $\mathrm{P}$ cycling on ecosystem retention. However, some forms of P (i.e., DOP) may have low bioavailability compared to inorganic P (Berman, 1988), which would increase its concentrations in the water column and lead to more movement downstream (Song et al., 2015). These forms of mobile $P$ could add to urban $P$ export and, over longer-time periods, may become bioavailable. In addition, the uptake of released sediment $\mathrm{P}$, regardless of chemical species, may also depend on the availability of other water column nutrients (e.g., nitrogen) and the form of nutritional limitation in primary producers (Jansson, 1988). Strongly P-limited algae should have a greater affinity for released P, which would reduce the export of dissolved P out of stormwater ponds. However, rates of P uptake and their relationships to nutrient status of microbial communities has yet to be examined in urban stormwater ponds.

Here we examined $\mathrm{P}$ dynamics in stormwater ponds with a special interest in interactions between sediments and the water column. We examined the quantities and types of $\mathrm{P}$ in the water and in sediments. We also examined rates of $\mathrm{P}$ release from urban stormwater pond sediments of different $\mathrm{P}$ forms and whether these release rates were sensitive to $\mathrm{O}_{2}$ concentrations. Finally, we examined algal uptake of $\mathrm{P}$ to increased supplies of inorganic and organic $\mathrm{P}$ to assess the ability of this process to reduce the subsequent export of this dissolved $\mathrm{P}$.

\section{Methods}

\subsection{Site Description}

We studied sediment $\mathrm{P}$ dynamics in six urban ponds in the town of Newmarket, Ontario, which is located north of Toronto, Ontario (see supporting information Table S1 for precise locations). All ponds were less than 20 years old and, for the most part, less than $2 \mathrm{~m}$ deep, which is typical of urban ponds in southern Ontario (McEnroe et al., 2013). Residential stormwater ponds in southern Ontario receive stormwater runoff from concrete drainage systems that link roadways, driveways, and home lots directly to the receiving pond. Previous work on stormwater ponds in Ontario, Canada, found them to be relatively eutrophic (McEnroe et al., 2013), to experience elevated summer temperatures (Song et al., 2013), to have water columns that frequently mix (Song et al., 2013), and to be a net exporter of internally produced autochthonous organic matter (Williams et al., 2013).

\subsection{Sediment and Water Sampling}

We sampled ponds and completed experiments during the summer (July-September) of 2016. Sediment cores for $\mathrm{P}$ analysis and release experiments were collected using a handheld polyvinyl chloride (PVC) coring device. This core sampling took place on an inflatable rubber raft in the main pool of each pond. Collected cores included the top 10- to 20-cm surficial sediments measured from the bottom of each pond. Immediately after collection, sediment samples were transferred intact into airtight containers and brought back to the laboratory in a cooler at $4{ }^{\circ} \mathrm{C}$. We stored core samples for sediment $\mathrm{P}$ characterization $(n=2-4)$ at $4{ }^{\circ} \mathrm{C}$ until processing, whereas additional cores, obtained for internal P flux experiments $(n=4)$, were kept in a dark 
environmental chamber at $20^{\circ} \mathrm{C}$ for the remainder of the experiment. Water samples for pond water column $\mathrm{P}$ analyses and bioassay experiments were collected from the same location in the pond. This water was screened through a $35-\mu \mathrm{m}$ mesh and transferred into $20-\mathrm{L}$ carboys. The water was brought back to the laboratory and filtered through $0.7-\mu \mathrm{m}$ glass fiber filters (GFFs) and $0.2-\mu \mathrm{m}$ polycarbonate filters. Samples of this filtered water were frozen for later $\mathrm{P}$ analysis or stored at $4{ }^{\circ} \mathrm{C}$ overnight prior to use in bioassays.

\subsection{Sediment $\mathbf{P}$ Characterization}

For P characterization, we transferred a sizable subsample ( 25\%) from each homogenized sediment core into a labeled polystyrene weigh boat, which was placed into a drying oven for $\sim 2$ days at $60^{\circ} \mathrm{C}$. After drying, the subsamples were transferred into a desiccator to cool. We then weighed two analytical subsamples ( 5-10 mg, total P [TP]; >1 g, labile P; 100-150 mg, Fe bound and 10-25 mg, Ca bound) from each core and transferred these samples into labeled tubes for $\mathrm{P}$ extraction (between 0 and 3 days after weighing). We separated $\mathrm{P}$ fractions using sequential extractions $\left(1-\mathrm{M} \mathrm{NH} \mathrm{N}_{4} \mathrm{Cl}, 0.1-\mathrm{M} \mathrm{NaOH}\right.$, and $\left.0.5-\mathrm{M} \mathrm{HCl}\right)$ following methods from Kapanen (2008). Samples for sediment TP analyses were ashed at $550{ }^{\circ} \mathrm{C}$ for $4 \mathrm{hr}$ in foilcapped glass vials to ensure that no $\mathrm{P}$ was lost due to handling. Samples were then autoclaved with a persulfate digest at $121^{\circ} \mathrm{C}$ for $1 \mathrm{hr}$. We then analyzed all fractions immediately using spectrophotometric methods described below (2.7). The organic P fraction was calculated as the difference between TP and the sum of the other three fractions.

\subsection{Sediment Core P Flux Experiments}

We used core incubations to characterize internal $\mathrm{P}$ flux rates under oxic and anoxic conditions. Cores collected from the field were held in an environmental chamber at $20^{\circ} \mathrm{C}$ for $24 \mathrm{hr}$ prior to the start of the experiment. We then replaced overlaying water in the core chamber with a known volume of either oxygenated or deoxygenated, prefiltered $(0.2 \mu \mathrm{m})$ water from the Otonobee River. The water was deoxygenated by bubbling with nitrogen gas prior to addition. Plastic caps were fixed onto deoxygenated cores to stop diffusion of oxygen, whereas caps were left off oxygenated cores to allow for oxygen diffusion. To prevent hypoxia, a stir bar apparatus was suspended in the middle of the water column and slowly rotated to add turbulent mixing for the entire 72-hr incubation. Cores were incubated with sampling occurring at 24- and 72-hr periods. During the 24-hr sampling, approximately two thirds of the water was removed from each core without disturbing underlying sediments to estimate P release during this period. We then replaced this water with corresponding amounts of oxygenated or deoxygenated water. Water samples collected at both time points were filtered through 0.2- $\mu \mathrm{m}$ GFFs. We stored samples for $\mathrm{P}$ analysis in amber bottles at $4{ }^{\circ} \mathrm{C}$ (dissolved organic $\mathrm{P}$ samples) or in 50-ml high-density polyethylene (HDPE) falcon tubes and frozen at $-20^{\circ} \mathrm{C}$ until analyses (TP and SRP).

\subsection{Sediment Peepers}

Sediment "peepers" were used to estimate P mobility in interstitial waters of pond sediments. To create the peepers, we drilled $2.5 \mathrm{~cm}$ holes in 125-ml HDPE sample bottles and secured $0.2-\mu \mathrm{m}$ polycarbonate filters over each hole. A PVC pipe apparatus was then constructed that securely held two HDPE bottles at a fixed depth in the pond sediments. Bottles were aligned with equally sized holes in the PVC pipe to allow interstitial water to diffuse across the membrane and into the sample bottle. We filled sample bottles with deoxygenated water and transported them into the field in a sealed container, which was also filled with deoxygenated water to maintain the lowest oxygen concentrations possible. Peepers were then deployed into the sediments so that bottles were located approximately 10 and $20 \mathrm{~cm}$ below the sediment surface. We left peepers in the sediments for a 2 -week incubation period before retrieving them. We then transferred the water samples into new bottles and transported them back to the laboratory on ice where the water was filtered through $0.2-\mu \mathrm{m}$ polycarbonate filters. We stored samples for P analysis in amber bottles at $4{ }^{\circ} \mathrm{C}$ (dissolved organic P samples) or in 50-ml HDPE falcon tubes and frozen at $-20{ }^{\circ} \mathrm{C}$ until analyses (TP and soluble reactive phosphorus, SRP).

\subsection{Bioassay Experiments}

Bioassay experiments were conducted to determine the inorganic $\mathrm{P}$ and DOP uptake by primary producers in the water column by comparing P removal rates and chlorophyll $a(\mathrm{Chl} a)$ concentrations after 72-hr incubations. We filled seventeen 1-L bags with pond water comprising three different treatments: six bags of 40:60 filtered:unfiltered water, four bags of 40:60 filtered:unfiltered water with added DOP, and four bags of 40:60 filtered:unfiltered water with added SRP. Phosphotidylcholine solution was added as a source of 

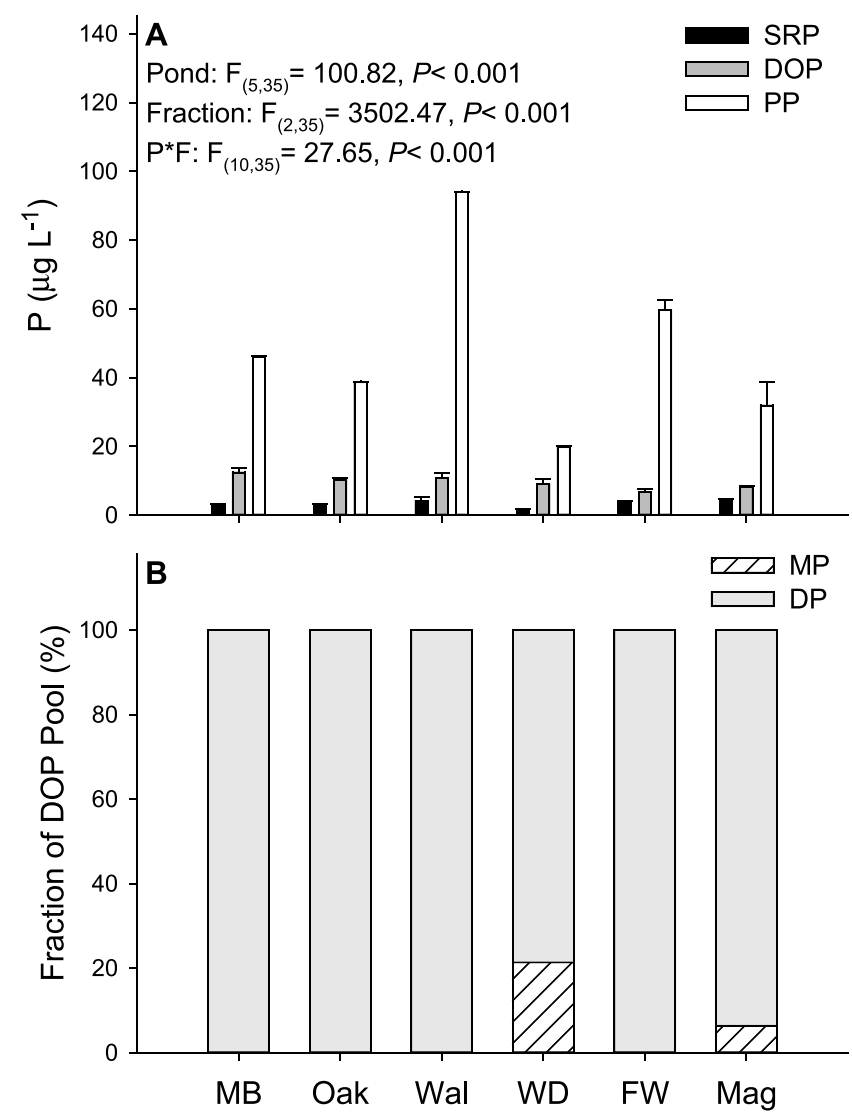

Figure 1. Phosphorus $(\mathrm{P})$ characterization in the water columns and within the dissolved organic $\mathrm{P}$ (DOP) pool of urban stormwater ponds. (A) Soluble reactive $\mathrm{P}(\mathrm{SRP}), \mathrm{DOP}$, and particulate $\mathrm{P}(\mathrm{PP})$ concentrations in the water column of each stormwater pond. Means and $95 \%$ confidence intervals are shown for each pond. $F$ ratios and $p$ values are reported from a two-way analysis of variance. (B) Percentage contribution of phosphomonoesters (MP) and phosphodiesters (DP) to the DOP pool for each studied stormwater pond. Ponds sampled in this study are abbreviated here and in other figures as follows: Walpole Crescent (Wal), Magna Centre (Mag), Ford Wilson (FW), Mulock and Bathurst (MB), Woodspring Avenue (Wood), and Oaktree Crescent (Oak).
DOP and $\mathrm{K}_{2} \mathrm{PO}_{4}$ solution was added as a source of SRP at a concentration of $100 \mu \mathrm{g} / \mathrm{L}$. While the phosphotidylcholine appeared to dissolve at the beginning of the experiment, there was visible precipitate in these bags at the end of the experiment. As such P was added in a DOP form in this treatment, but its concentration was likely lower than planned, which complicates easy interpretation of these results. Additional water from these treatments was also saved to determine initial DOP, SRP, Chl $a$ total dissolved nitrogen (TDN) and particulate $\mathrm{P}$ (PP) concentrations. We then placed experimental bags into a basket-like structure, which were incubated outdoors in a stormwater pond at Trent University for $72 \mathrm{hr}$. After the incubation period, the bags were collected, water was filtered onto a 0.7- $\mu \mathrm{m}$ GFFs, and filters were either dried at $60{ }^{\circ} \mathrm{C}$ and stored at $20{ }^{\circ} \mathrm{C}$ for PP analysis or stored in the dark at $-20{ }^{\circ} \mathrm{C}$ until subsequent $\mathrm{Chl} a$ analysis described below. Water for each bag was then filtered through $0.2-\mu \mathrm{m}$ polycarbonate filters and stored at $-20{ }^{\circ} \mathrm{C}$ for subsequent SRP, DOP, and TDN analyses as describe below.

\subsection{Chemical Analyses}

We measured water column SRP and P released from sediment incubations using molybdate-blue ascorbic acid colorimetry (American Public Health Association (APHA), 1992) and absorbance spectroscopy measurements (Cary-50, Varian, Palo Alto, CA). Water column TDP was measured similarly following a persulfate digest described above and DOP concentrations were estimated as the difference between TDP and SRP. We also directly characterized DOP in the water column and peeper samples following a procedure by Song et al. (2015) using phosphomonoesterase and phosphodiesterase to hydrolyze MP and DP fractions and then measured these fractions as SRP. Concentrations of DOP calculated by difference could not be made for peeper samples due to visible $\mathrm{P}$ precipitation in these TDP samples, so peeper DOP was calculated as the sum of MP and DP. All other DOP measurements reported in the study are calculated by TDP-SRP difference measurements. We determined Chl $a$ concentrations by extracting pigments from filters using a 24-hr cold ethanol extraction (Marker et al., 1980) followed by spectrofluorometry (Cary Eclipse Fluorometer, Varian Inc.). TDN concentrations were determined using second derivative spectroscopy method following a persulfate digest (Crumpton et al., 1992).

\subsection{Statistical Analyses}

Prior to conducting parametric statistics, all data were log transformed to better meet normality and variance assumptions. We examined differences in water column $\mathrm{P}$ concentrations using a factorial two-way analysis of variance (ANOVA) with pond and the type of $\mathrm{P}$ fraction each treated as a factor. We also used a factorial two-way ANOVA to compare release rates of SRP and DOP from sediment peepers among ponds and flux rates of SRP and DOP of core experiments through time. Cores from one pond, Woodspring Avenue, went anoxic overnight leading to considerable $\mathrm{P}$ flux before the core experiments could be initiated; therefore, this pond was omitted from the core flux analysis. For bioassays, we conducted $t$ tests to compare the differential uptake rates of SRP and DOP, their incorporation into algal PP, and their effects on algal growth rates within each pond. Finally, we used ordinary least squares regressions to examine the effects of pond TDN:TDP ratios on algal biomass responses to SRP and DOP additions.

\section{Results}

\subsection{Water Column and Sediment P Fractions}

In the water column of ponds, $\mathrm{PP}$ was found to be the most prevalent form ( $\sim 60-80 \%$ of TP) of $\mathrm{P}$. The remaining $\mathrm{P}$ was found in dissolved forms, which was largely composed of DOP $(\sim 9.8 \mu \mathrm{g} / \mathrm{L})$ with relatively lower 


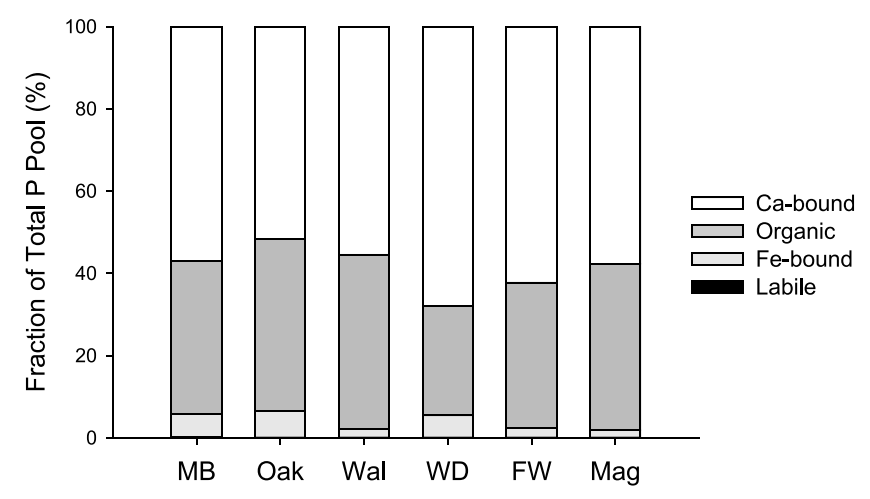

Figure 2. Sediment $\mathrm{P}$ fractions shown as a percentage of the total $\mathrm{P}$ measured in urban stormwater ponds. Sediment fraction abbreviations include iron $(\mathrm{Fe})$ bound and calcium $(\mathrm{Ca})$ bound. Note that labile $\mathrm{P}$ concentrations were too small to be depicted on the figure.
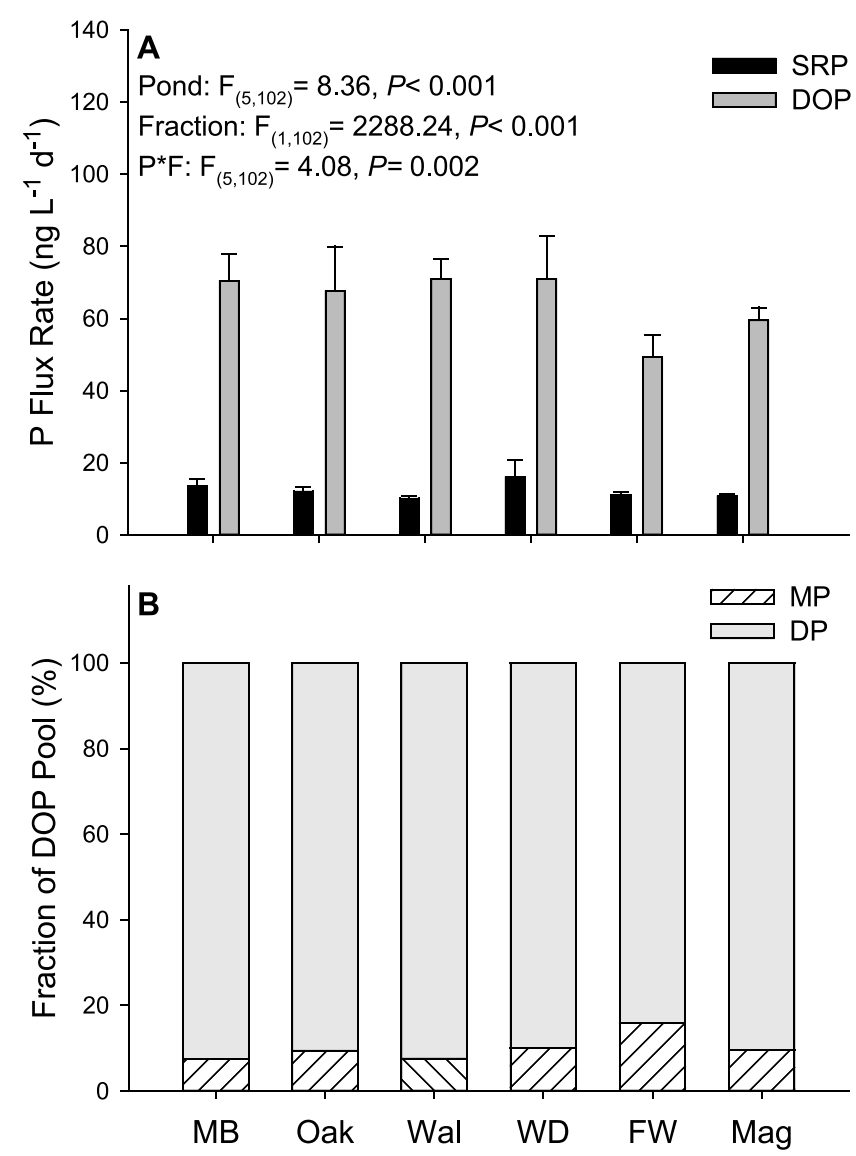

Figure 3. Phosphorus (P) characterization in sediment peeper samples. (A) Rates of concentration increase for soluble reactive phosphorus (SRP) and organic $\mathrm{P}$ in peepers incubated in urban stormwater ponds. Means and $95 \%$ confidence intervals are shown for each pond. $F$ ratios and $p$ values are reported from a two-way analysis of variance. (B) Percentage contribution of phosphomonoesters (MP) and phosphodiesters (DP) are also shown for each site.
SRP concentrations $(\sim 3.3 \mu \mathrm{g} / \mathrm{L}$; Figure 1$)$. While we detected significant pond $\times$ fraction interactive effects on water column $\mathrm{P}$ concentrations, the same order of $\mathrm{P}$ prevalence $(\mathrm{PP}>\mathrm{DOP}>\mathrm{SRP}$ ) was found in all of the ponds we studied (Figure 1). In the DOP, DP was the predominant class and nearly no MP was detected in the water column in these stormwater ponds (Figure 1). Pond sediment $P$ fractions were dominated by two fractions, Ca-bound $\mathrm{P}$ fraction and an organic $\mathrm{P}$ fraction. Together these two forms of $\mathrm{P}$ composed $>90 \%$ of sediment $\mathrm{P}$ in each pond (Figure 2). Other inorganic $\mathrm{P}$ forms accounted for much smaller proportions of sediment $\mathrm{P}$ with $\mathrm{Fe}$-bound $\mathrm{P}$ accounting for about $6.5 \%$ and labile $\mathrm{P}$ contributing $<0.15 \%$ of the total sediment $\mathrm{P}$ pool (Figure 2).

\subsection{Sediment $P$ Mobility and Release}

With our peepers, we measured fluxes of mobile $\mathrm{P}$ moving laterally through the sediments. Of the dissolved $\mathrm{P}$ that diffused into peepers, we mostly found DOP and relatively less SRP in our samples (Figure 3). Despite a significant pond $\times$ fraction interactive term, most of the variation in sediment $\mathrm{P}$ release was associated with the differences between DOP and SRP diffusion rates (Figure 3). We further found that most of the DOP was in a DP form and less than $20 \%$ was in a MP form. In our experiments where we measured sediment $\mathrm{P}$ flux rates from cores held in the laboratory, significant amounts of $\mathrm{P}$ were released especially under low oxygen concentrations. Under these low oxygen conditions, chamber flux rates were similar between inorganic and DOP fractions (Figure 4a). In contrast, inorganic $P$ flux rates were much lower under high oxygen conditions with rates of SRP flux negative for both days. Although DOP flux rates were two times lower in high oxygen conditions, they remained positive even under high oxygen conditions (Figure $4 b$ ).

\subsection{Algal Bioassay Experiments}

In the algal bioassays, we examined the fate of two forms of $\mathrm{P}$, inorganic $\mathrm{P}$ and a single type of DOP, provided to stormwater pond algal communities. In four of the six ponds, we found reduced concentrations of both types of added dissolved $\mathrm{P}$ over the course of the 3-day incubation (Figure 5a). This loss of dissolved $\mathrm{P}$ was accompanied by significant algal growth in only two ponds (Figure 5b) as indicated by increased Chl $a$ in both these ponds (Figure 5c). While PP increased in all experimental containers provided SRP, more variable accumulation of PP was seen in the DOP added bioassays (Figure 5c). In addition, PP in SRP added bioassays was higher than that in the DOP added bioassays in four out of six treatment ponds. We also found that bioassay algal growth rates strongly correlated to the TDP:TDN ratio in the water column of each respective pond (Figure 5d).

\section{Discussion}

Urban stormwater ponds are a prominent water feature in many newer (<25 years old) residential neighborhoods in North America. Their original purpose was to reduce local floods associated with increased impervious surface areas (Hogan \& Walbridge, 2007). A second set of functions have been increasingly promoted including that of being a nutrient sink and of improving water quality. Consequently, the design criteria of many urban ponds in Canada are partly based on engineering principles thought to enhance P capture and storage (Marsalek, 2002). In particular, many stormwater ponds are built shallow and to have a 

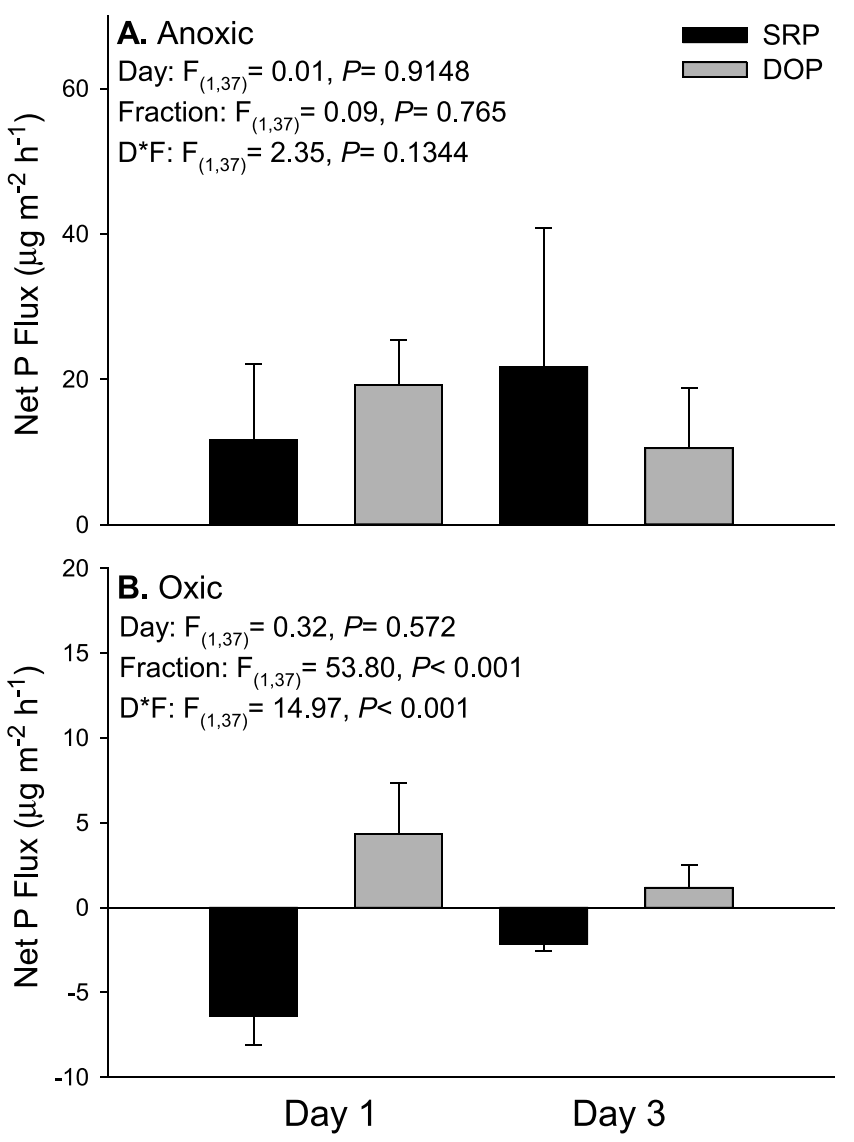

Figure 4. Phosphorus flux rates under (A) anoxic and (B) oxic conditions in laboratory sediment core incubations. Shown are rates of soluble reactive phosphorus (SRP) and dissolved organic P (DOP) flux from sediments on days 1 and 3 . Means and $95 \%$ confidence intervals are shown for each $\mathrm{P}$ fraction. $F$ ratios and $p$ values are reported from two-way analyses of variance. Note that rates are expressed as net fluxes, which include sediment $\mathrm{P}$ release/uptake and any biological uptake or sorption that might have occurred in the experimental chambers. high sediment surface area to pond volume ratio to ensure a well-mixed, homogeneous water column that keeps sediments oxygenated. In addition to deterring inorganic $\mathrm{P}$ release from the sediments, this type of design is intended to maximize the capture of suspended solids by reducing the settling distance for nutrient rich particles (Maavara et al., 2015; Williams et al., 2013).

Past estimates for the retention of total suspended solids found $\sim 85 \%$ of these particles are captured from inflowing water (Williams et al., 2013). The high retention efficiency of total suspended solids suggests the sinking-retention model used for pond design works well for nonreactive particles (Zoppou, 2001). However, lower and variable retention of biogeochemically dynamic elements (i.e., $\mathrm{N}$ and $\mathrm{P}$ ) suggests more complicated removal and burial processes at play for dissolved nutrients and that a closer examination of these elements is needed to understand their fate in urban ponds. For example, water column $\mathrm{P}$ in urban ponds is usually split between DOP and PP (Song et al., 2015), which indicates a sinking-retention mechanism may be only partially successful in reducing the export of this element. Further, P retention could be reduced if the particle $\mathrm{P}$ removed by sedimentation is susceptible to rerelease from the sediments (Song et al., 2017). The primary objective of this research was to examine the mobility of different $\mathrm{P}$ forms in urban stormwater sediments and its fate in the water column.

We found most of the sediment $\mathrm{P}$ to be in one of two forms ( $\mathrm{Ca}$ bound and organic) in the urban stormwater ponds. This result matches previous results of sediment $\mathrm{P}$ speciation in other urban ponds of this region (Song et al., 2015), which is likely a result of significant quantities of P-rich organic matter accumulating in the sediments of these relatively eutrophic ecosystems. While the presence of high quantities of sediment $\mathrm{P}$ have been previously reported, the movement and fate of this $\mathrm{P}$ has yet to be examined. We found relatively more DOP than SRP moving into in situ peepers and, of this mobile DOP, most of it was in DP form. This is perhaps not surprising given the prevalence of organic $\mathrm{P}$ in the sediments and relatively limited $\mathrm{P}$ mass of more mobile, inorganic forms. In addition, this result may reflect relatively strong binding of inorganic $\mathrm{P}$ to $\mathrm{Ca}$ and mineral fractions (such as $\mathrm{Al}$ ) in the sediment and less binding of DOP, particularly DP. It thus appears that when particulate forms of organic $\mathrm{P}$ in sediments are converted to DOP, especially DP, that this $\mathrm{P}$ form is relatively mobile within urban pond sediments.

We further assessed P mobility from urban pond sediments by measuring $\mathrm{P}$ release from sediment cores incubated in the laboratory. Over the course of 4 days, we measured substantial releases of $\mathrm{P}$ from cores that varied with water $\mathrm{O}_{2}$ concentrations. Under low $\mathrm{O}_{2}$ conditions, both inorganic and organic $\mathrm{P}$ forms were released at elevated rates over the course of the 3-day incubation. Brief periods of anoxia may result during short-lived thermal stratification produced by especially calm conditions (Song et al., 2013) and yield pulses of inorganic P. Given the small pool of mineral bound P that we measured in pond sediments, it is unclear whether these fluxes would affect water column $\mathrm{P}$ concentrations. Our results also indicate that organic $\mathrm{P}$ is released at a slower but more consistent rate regardless of water column $\mathrm{O}_{2}$. Altogether, our results demonstrate that dissolved $\mathrm{P}$ can be released from urban ponds but the type of this $\mathrm{P}$ depends strongly on water column dissolved oxygen concentration. It appears that well-oxygenated water columns on their own are insufficient to eliminate release of $\mathrm{P}$ from organic-rich stormwater pond sediments. Pond sediments may act more as a temporary P storage site given these possible fluxes of dissolved P back into the water column.

The dissolved P released from urban pond sediments will ultimately either be exported from the pond during storms event or returned back to pond sediments following uptake by pond biota and subsequent sedimentation. This fate (export or uptake sedimentation) of released $\mathrm{P}$ should depend on the form of $\mathrm{P}$ released, the 

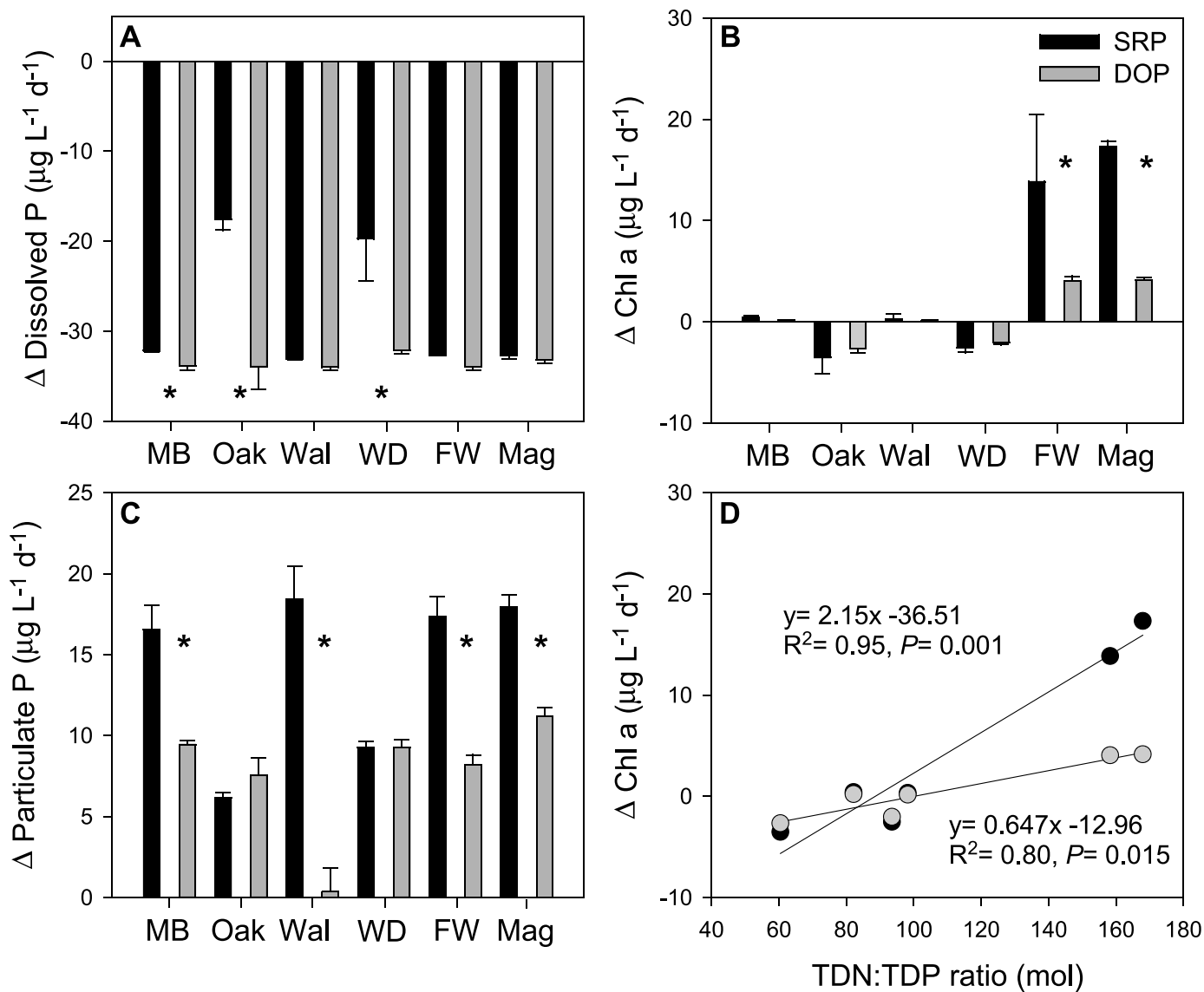

Figure 5. Algal responses to phosphorus (P) in nutrient-amended bioassays. Changes in (A) dissolved $\mathrm{P}$ uptake, (B) chlorophyll $a$ (Chl $a$ ) concentrations, and (C) particulate $\mathrm{P}$ between treatments that added soluble reactive phosphorus (SRP) and dissolved organic phosphorus (DOP) for each pond. Asterisk (*) indicates significant differences among treatments $(p<0.05)$ for each pond. Means and 95\% confidence intervals are shown for each P fraction. (D) Relationship between $\mathrm{Chl} a$ increase and the molar ratio of total dissolved nitrogen and total dissolved P ratios (TDN:TDP) for bioassays receiving each P fraction. $R^{2}$ and $p$ values are reported for ordinary least squares regressions analysis.

P demand by pond microbial communities, and the water residence time of the pond (Pettersson, 1998; Søndergaard et al., 2003). We found that significant quantities of dissolved P could be removed by algal communities in our bioassay experiments. Consistent with prior work, we found that this reduction was relatively greater for inorganic $\mathrm{P}$ in four of six study ponds, which is the form of $\mathrm{P}$ that is often more amendable to algal uptake (e.g., Cotner \& Wetzel, 1992). While uptake rates of DOP by pond microbes were much lower, this may have been influenced by the form of DOP used in our experiments, which was not highly soluble. Since our DOP was not entirely soluble, our measured uptake rates of DOP in our algal bioassays should not be considered as representative of algal removal of DOP in general. Regardless, we found significant quantities of DOP already in pond water columns at the start of our experiments and subsequent removal of SRP by algae in these same experiments. These two results further indicate that water column DOP is relatively less bioavailable to primary producers in urban stormwater ponds.

Our experimental manipulation of DOP in the bioassay experiment was not informative as the chosen form of DOP, phosphotidylcholine, was relatively insoluble, and did not remain in solution over the course of our experiment. We considered a number of possible organic $\mathrm{P}$ forms for this experiment but many did not appear to be environmentally relevant or chemically similar to the DP forms of DOP prevalent in urban stormwater ponds studied here. As there is considerable value in assessing the in situ bioavailability of different DOP sources to pond algal communities, we recommend that future studies better characterize the chemical speciation of DOP and identify chemical species that would be more appropriate and feasible for use in these experiments. 
While we found that SRP was removed in all ponds, this uptake was not accompanied by increased algal growth in several of our pond samples. Phosphorus uptake can become uncoupled from algal growth when other elements are acutely limiting. This excess P uptake is consistent with luxury consumption (Elrifi \& Turpin, 1985) and indicates here that other nutrients or resources were possibly limiting. Given the relationship between water column TDN:TDP ratios and Chl $a$ accumulation, it appears that low nitrogen may be limiting algal growth in several of the studied stormwater ponds. If so, these $\mathrm{N}$ constraints on primary production may reduce $P$ fluxes into particulate forms and longer-term storage in pond sediments. This type of additional stoichiometric constraint on P retention, both on algal uptake and subsequent detrital decomposition, should be examined in the future.

We found significant quantities of $\mathrm{P}$ in the sediments of stormwater ponds, which has also been reported in urban ponds in Minnesota, USA (Olsen, 2017). In our study region, a large fraction of $\mathrm{P}$ in the sediments of nearby wetlands and streams was also found as organic P (Audette et al., 2018). We found that much of this organic $\mathrm{P}$ was mobile and released from sediment regardless of water column oxygenation. While our study focused on quantifying four $\mathrm{P}$ fractions (Figure 2), future studies could more finely characterize $\mathrm{P}$ fractions and their mobility/lability under variable biogeochemical and redox conditions. In particulate, there appear to be important but understudied $\mathrm{P}$ forms in aquatic ecosystems, such as nanoparticle phosphorus (i.e., River \& Richardson, 2018). The prevalence of these P forms in urban environments has yet to be assessed and may help understand patterns described here.

Altogether, our results thus indicate that the internal cycling of DOP is a significant biogeochemical feature of stormwater ponds. As DOP dynamics could vary seasonally given possible differences in inflowing $\mathrm{P}$ concentrations and types, hydrological turnover times, primary production, and microbial processes, the significance of these processes may be limited to a short period in midsummer. As such, internal P cycling and factors that possibly constrain it should be considered in future studies of these urban ecosystem functioning. In addition, design criteria for stormwater management facilities should be revisited to better consider and address the biogeochemical realities of these urban aquatic ecosystems.

\section{Acknowledgments}

We thank Ty Gerhke of Trent University and Chandler Eves of the Lake Simcoe Region Conservation Authority for assistance with field sampling and laboratory experiments. This research was funded, in part, by Environment and Climate Change Canada through the Lake Simcoe Clean-up Fund. All data used in this manuscript can be obtained from figshare website (https://doi.org/10.6084/ m9.figshare.7387688.v1).

\section{References}

American Public Health Association (APHA) (1992). APHA Method 3500-MG: Standard Methods for the Examination of Water and Wastewater (18th ed.). Washington, DC: American Public Health Associattion.

Audette, Y., O'Halloran, I. P., Nowell, P. M., Dyer, R., Kelly, R., \& Voroney, R. P. (2018). Speciation of phosphorus from agricultural muck soils to stream and lake sediments. Journal of Environmental Quality, 47, 884-892. https://doi.org/10.2134/ jeq2018.02.0068

Berman, T. (1988). Differential uptake of orthophosphate and organic phosphorus substrates by bacteria and algae in Lake Kinneret. Journal of Plankton Research, 10, 1239-1249.

Brunberg, A. K., \& Boström, B. (1992). Coupling between benthic biomass of Microcystis and phosphorus release from the sediments of a highly eutrophic lake. Hydrobiologia, 235-236, 375-385. https://doi.org/10.1007/BF00026227

Carpenter, S. R., Caraco, N. F., Correll, D. L., Howarth, R. W., Sharpley, A. N., \& Smith, V. H. (1998). Nonpoint pollution of surface waters with phosphorus and nitrogen. Ecological Applications, 8, 559-568.

Comings, K. J., Booth, D. B., \& Horner, R. R. (2000). Storm water pollutant removal by two wet ponds in Bellevue, Washington. Journal of Environmental Engineering, 126, 321-330.

Cotner, J. B., \& Wetzel, R. G. (1992). Uptake of dissolved inorganic and organic bphosphorus compounds by phytoplankton and bacterioplankton. Limnology and Oceanography, 37, 232-243.

Crumpton, W. G., Isenhart, T. M., \& Mitchell, P. D. (1992). Nitrate and organic N analyses with second-derivative spectroscopy. Limnology and Oceanography, 37, 907-913.

Duan, S., Newcomer-Johnson, T., Mayer, P., \& Kaushal, S. (2016). Phosphorus retention in stormwater control structures across streamflow in urban and suburban watersheds. Water, $8,390$.

Easton, Z. M., Gérard-Marchant, P., Walter, M. T., Petrovic, A. M., \& Steenhuis, T. S. (2007). Identifying dissolved phosphorus source areas and predicting transport from an urban watershed using distributed hydrologic modeling. Water Resources Research, 43 , W11414. https://doi.org/10.1029/2006WR005697

Elrifi, I. R., \& Turpin, D. H. (1985). Steady-state luxury consumption and the concept of optimum nutrient ratios: A study with phosphate and nitrate limited Selenastrum minutum (chlorophyta) 1. Journal of Phycology, 21, 592-602.

Gold, A. C., Thompson, S. P., \& Piehler, M. F. (2017a). Coastal stormwater wet pond sediment nitrogen dynamics. Science of the Total Environment, 609, 672-681.

Gold, A. C., Thompson, S. P., \& Piehler, M. F. (2017b). Water quality before and after watershed-scale implementation of stormwater wet ponds in the coastal plain. Ecological Engineering, 105, 240-251.

Hogan, D. M., \& Walbridge, M. R. (2007). Best management practices for nutrient and sediment retention in urban stormwater runoff. Journal of Environmental Quality, 36, 386-395.

Hupfer, M., \& Lewandowski, J. (2008). Oxygen controls the phosphorus release from lake sediments-A long-lasting paradigm in limnology. International Review of Hydrobiology, 93, 415-432. https://doi.org/10.1002/iroh.200711054

Jansson, M. (1988). Phosphate uptake and utilization by bacteria and algae. Hydrobiologia, 170, 177-189.

Kapanen, G. (2008). Phosphorus fractionation in lake sediments. Estonian Journal of Ecology, 57. 
Kaye, J. P., Groffman, P. M., Grimm, N. B., Baker, L. A., \& Pouyat, R. V. (2006). A distinct urban biogeochemistry? Trends in Ecology \& Evolution, 21, 192-199. https://doi.org/10.1016/j.tree.2005.12.006

Maavara, T., Parsons, C. T., Ridenour, C., Stojanovic, S., Dürr, H. H., Powley, H. R., \& van Cappellen, P. (2015). Global phosphorus retention by river damming. Proceedings of the National Academy of Sciences of the United States of America, 112, 15,603-15,608. https:// doi.org/10.1073/pnas.1511797112

Marker, A. F. H., Nusch, E. A., Rai, H., \& Riemann, B. (1980). The measurement of photosynthetic pigments in freshwaters and standardization of methods: Conclusions and recommendations. Archive fur Hydrobiologie, Beiheft Ergebnisse der Limnologie, 14, 91-106.

Marsalek, J. (2002). Water reuse and recycling, a Workshop. Canadian Council of Ministers of the Environment.

McEnroe, N. A., Buttle, J. M., Marsalek, J., Pick, F. R., Xenopoulos, M. A., \& Frost, P. C. (2013). Thermal and chemical stratification of urban ponds: Are they 'completely mixed reactors'? Urban Ecosystems, 16, 327-339.

Olsen, T. (2017). Phosphorus dynamics in stormwater ponds. M.S. Thesis. University of Minnesota. St. Paul, Minnesota, USA.

Paul, M. J., \& Meyer, J. L. (2001). Streams in the urban landscape. Annual Review of Ecology and Systematics, 32, $333-365$.

Pettersson, K. (1998). Mechanisms for internal loading of phosphorus in lakes. Hydrobiologia, 373/374, 21-25. https://doi.org/10.1023/ A:1017011420035

River, M., \& Richardson, C. J. (2018). Stream transport of iron and phosphorus by authigenic nanoparticles in the Southern Piedmont of the U.S. Water Research, 130, 312-321. https://doi.org/10.1016/j.watres.2017.12.004

Sinke, A. J. C., Cornelese, A. A., Keizer, P., Tongeren, O. F. R., \& Cappenberg, T. E. (1990). Mineralization, pore water chemistry and phosphorus release from peaty sediments in the eutrophic Loosdrecht lakes, The Netherlands. Freshwater Biology, 23, 587-599. https:// doi.org/10.1111/j.1365-2427.1990.tb00297.x

Søndergaard, M., Kristensen, P., \& Jeppesen, E. (1993). Eight years of internal phosphorus loading and changes in the sediment phosphorus profile of Lake Søbygaard, Denmark. Hydrobiologia, 253, 345-356. https://doi.org/10.1007/BF00050760

Søndergaard, M., Peder Jensen, J., \& Jeppesen, E. (2003). Role of sediment and internal loading of phosphorus in shallow lakes. Hydrobiologia, 506-509, 135-145.

Sonderup, M. J., Egemose, S., Hansen, A. S., Grudinina, A., Madsen, M. H., \& Flindt, M. R. (2016). Factors affecting retention of nutrients and organic matter in stormwater ponds. Ecohydrology, 9, 796-806.

Song, K., \& Burgin, A. J. (2017). Perpetual phosphorus cycling: Eutrophication amplifies biological control on internal phosphorus loading in agricultural reservoirs. Ecosystems, 20, 1483-1493. https://doi.org/10.1007/s10021-017-0126-Z

Song, K., Winters, C., Xenopoulos, M. A., Marsalek, J., \& Frost, P. C. (2017). Phosphorus cycling in urban aquatic ecosystems: Connecting biological processes and water chemistry to sediment $\mathrm{P}$ fractions in urban stormwater management ponds. Biogeochemistry, 132, 203-212.

Song, K., Xenopoulos, M. A., Buttle, J. M., Marsalek, J., Wagner, N. D., Pick, F. R., \& Frost, P. C. (2013). Thermal stratification patterns in urban ponds and their relationships with vertical nutrient gradients. Journal of Environmental Management, 127, 317-323.

Song, K., Xenopoulos, M. A., Marsalek, J., \& Frost, P. C. (2015). The fingerprints of urban nutrients: Dynamics of phosphorus speciation in water flowing through developed landscapes. Biogeochemistry, 125, 1-10. https://doi.org/10.1007/s10533-015-0114-3

Tixier, G., Lafont, M., Grapentine, L., Rochfort, Q., \& Marsalek, J. (2011). Ecological risk assessment of urban stormwater ponds: Literature review and proposal of a new conceptual approach providing ecological quality goals and the associated bioassessment tools. Ecological Indicators, 11, 1497-1506.

Turner, B. L., \& Newman, S. (2005). Phosphorus cycling in wetland soils. Journal of Environmental Quality, 34, $1921-1929$.

Walsh, C. J., Roy, A. H., Feminella, J. W., Cottingham, P. D., Groffman, P. M., \& Morgan, R. P. (2005). The urban stream syndrome: Current knowledge and the search for a cure. Journal of the North American Benthological Society, 24, 706.

Williams, C. J., Frost, P. C., \& Xenopoulos, M. A. (2013). Beyond best management practices: Pelagic biogeochemical dynamics in urban stormwater ponds. Ecological Applications, 23, 1384-1395.

Zoppou, C. (2001). Review of urban storm water models. Environmental Modelling \& Software, 16, 195-231. 